\title{
Community Empowerment in Rehabilitation of Forests and Critical Lands on The Sekaroh Area
}

\author{
S Suwardji \\ Department of Soil Science \\ University of Mataram \\ Mataram, Indonesia \\ Sri Tejowulan* \\ Department of Soil Science \\ University of Mataram \\ Mataram, Indonesia \\ sritejowulan@unram.ac.id
}

\author{
P Parman \\ Faculty of Law \\ University of Mataram \\ Mataram, Indonesia
}

Agil Alaydrus

Biology Education Study Program

University of Mataram

Mataram, Indonesia

\author{
Abdul Syukur \\ Biology Education Study Program \\ University of Mataram \\ Mataram, Indonesia \\ Ahmad Raksun \\ Biology Education Study Program \\ University of Mataram \\ Mataram, Indonesia
}

\begin{abstract}
Forests and land degradation in the Sekaroh region of East Lombok areas has reached a very severe level. Since the 1990s the government of Indonesia has made various efforts to rehabilitate forests and critical land in this area on a massive scale, but data showed that the success rate was far from expectations. The paper presented in this international conference was the two years participatory study that is very relevant to the massive destruction of forests and land that occurred in the Province of West Nusa Tenggara. The method used in this study was Participatory Rapid Appraisal (PRA) method which involves various stakeholders in the forest and land rehabilitation efforts. The results of the 2 year participatory study were able to encourage a ways to overcome the problems of forests and land degradation in the Village of Sekaroh and Pemongkong through a development paradigm based on both natural resources and human resources by emphasizing community learning and empowerment as development capital. The social capital paradigm developed through real learning is social capital that is based on 'togetherness', namely by trying to see the positive roles of social institutions to be played in the learning process in the management of forests and land degradation in Sekaroh and Pemongkong villages. The action learning process that has been carried out has succeeded in encouraging collaboration among institutions such as religious institution, customary institution, local government and the Working Group on Forest and Land Degradation.
\end{abstract}

Keywords-Community empowerment, Forest and Land Rehabilitation, Critical Forest and Land, Participatory Rapid Appraisal (PRA)

\section{INTRODUCTION}

Forests and land are important natural resources on which various kinds of life depend. Plants, animals and humans all utilize forest and land resources and their ecosystems to meet with their various needs for life. Regrettably, the condition of forests and land in West Nusa Tenggara (NTB) Province has experienced degradation to a level that is severe enough that it can no longer function and be used sustainably to improve the welfare of the people living around it.
In Sekaroh and Pemongkong Villages, Jerowaru Sub District, District of East Lombok, the forest and land areas have also been severely damaged. Deforestation, expropriation of forest land, and use of forest land for agriculture have caused forest and land degradation, resulting in severe socioeconomic, socio-cultural and environmental impacts.

According to the stories of traditional elders from Sekaroh and Pemongkong villages, in the early 1970s the Sekaroh forest area (called Gawah Sekaroh) was still a very dense forest with a wide variety of terrestrial flora and fauna diversities. Not many humans dare to enter Gawah Sekaroh except for cattle and buffalo herders both from Central and East Lombok. In contrast to the current situation, Gawah Sekaroh is no longer a forest with densely trees but only a protected forest area that is widely used for illegal cultivation and grazing. Only a small part (about 400 Ha over more than 3500 hectares) of the existing forest area is currently still in the form of forest with very minimal conditions.

The government through various related agencies since 1990 has made various efforts to reforest and rehabilitate the Sekaroh forests and land by planting hundreds of thousands and even millions of tree seedlings into this region. However, the fact shows that this activity is not able to improve the condition of the damaged forest and land.. The number of the degraded forest and land in Sekaroh and Pemongkong continues to increase and is very difficult to control. The main obstacle to forest and critical land management in the Sekaroh and Pemongkong areas seems lies in the biophysical conditions of the land and the socio-economic and cultural problems of the people. The Sekaroh and Pemongkong areas, which cover an area of over 12,000 hectares, are located above the land resulting from the uplifting of sea surface landform (Tarningsih et al, 2010). The land develops from the limestone source rock from the deposits of marine biota and having very dry climatic conditions, classified as E4 by Oldeman et al. (1980). This E4 region of Sekaroh and Pemongkong are very dry, erratic, and have low soil fertility, causing the productivity of food crops in this land to be very low yearly. This is the main cause of the 
high poverty rate and has an indirect effect on forest and land damage (Suwardji et al 2019).

This situation is exacerbated by the unfavorable socioeconomic and cultural conditions of the community, such as a growing population, unresolved poverty, low levels of education, and scarcity of alternative employment opportunities outside of agriculture and forestry. In addition, forest and land damage is also caused by a lack of understanding and concern for the community and government on the importance of environmental conservation.

If this situation does not get serious attention, the number of forests and critical lands will continue to increase and in the future this situation will threaten the sustainability of development and the future of the community's life in the area. Therefore, efforts to conserve critical forests and land must continue to be considered and supported by all parties.

Realizing the complex problems in forest and critical land management in Sekaroh and Pemongkong Villages, the Provincial Forest and Land Working Group for Forest and Land (LWG) in collaboration with Regional of Planning Agency of West Nusa Tenggara Province and Aus AID Denpasar tried to explore the root causes of forest destruction and land degradation and try to find an alternative solutions to restore the condition of forests and critical land to a better and healthier condition. The participatory work of the Land Working Group for Forest and Lands in NTB Province has received support from the Aus-AID Project Australia which deals with forest and critical land issues.

The experience of participatory studies on forest and critical land management efforts for two years in the Sekaroh and Pemongkong regions is written in this paper as an experience that can be developed and studied further by the younger generation of millenials and other stakeholders so that in the future they are able to overcome the various problems of forest and land degradation in this area and NTB that have not been resolved until now.

\section{METHODS}

The method used in this study is the participatory rapid appraisal (PRA) method, a method that is believed to be able to build togetherness and access of all stakeholder roles both directly and indirectly to the problems found in forest and critical land management.

The use of participatory methods with action learning aims to change the mindset and negative behavior of all stakeholders in the management of forests and critical lands facilitated by the Forest and Land Working Group (Pokja). In addition, this participatory method empowers communities to understand better regarding their right: (1) to environmental resources around forests and critical land and their obligations and responsibilities to manage it in order to achieve environmental quality forest and critical land that it demands (awareness), (2) to demands for a sustainable forest and land environment (empowered), (3) to be able to take local initiatives to overcome forest and land environmental problems (independent), and (4) to deliver aspirations for demands that the forest and land environment become a mainstay of life not only for present generations but also for future generations (fighting for aspiration). Ten people from the younger generation and community leaders from Sekaroh and Pemongkong villages have been actively involved in this study. Activities begin with PRA method training activities by running the basics of PRA techniques namely are: (1) historical flow, (2) welfare classification, (3) trends and changes, (4) institutional diagrams, (5) decision making, (6) ) social and resource mapping, (7) ranking matrices, (8) seasonal calendars, (9) transects, (10) garden sketches, (11) input and expenditure flows, (12) livelihood analysis, and (13) structured interviews (Nusa Tenggara Highlands Consortium, 2000). In the implementation the PRA method was combined with several other methods such as: lectures, brainstorming, focus group discussions (FGD), simulations, demonstrations, role playing, and field work.

The implementation of activities is carried out into five following stages. The first stage is outreach activities, namely: providing information to the public about the sustainability of the implementation program that has been compiled with the community; conditioning the community to have both time and energy readiness to implement the program; to form a small team whose task is to hold meetings with community groups in making a collective agreement on the process of implementing activities regardless time and place of implementation of training activities, technical arrangement of logistics and accommodation during training activities, and safety during training activities; to give a role to the community in the learning process to let community to organize activities so that a sense of responsibility grows towards the activity process and the results achieved; making a Work Contract with the community, Pokja facilitates the process of implementing activities to make an implementation agreement.

The second stage is carried out the outreach, namely: to improve the group's ability to formulate and determine the form of a work contract as a guideline for implementing activities; training in Class and Field, stage 2 is a continuation of stages. At this stage the facilitator prepares training materials and discussion spaces for the community concerning: (1) compilation of participatory joint work plans for the management of forests and critical lands, (2) techniques for implementing activities based on participatory work plans for critical forest and land management, (3) Techniques for formulating the results of the discussion. This stage aims to directly train the community to identify real problems or real conditions experienced by the community based on priorities to be organized into programs and the efforts or solutions needed to solve them). The third stage is plenary. This plenary stage is conducted to present the results obtained during a certain activity period at the hut level and then other plenary participants respond or comment. The plenary was attended by all representatives of the hut, government representatives, Toga and Toma, and other stakeholders as well as all members of the Forest and Land Working Group/Pokja. The objectives of the plenary are: (1) to refine and review the results that have been obtained at the previous hut level, (2) to train the community to express and present the results in front of the forum and (3) to 
provide opportunities for other participants to argue and improve the results presented. The fourth stage is reflection. This reflection stage is a very important part because reflection can provide an overview of the weaknesses that occur to be corrected in the next process. Reflection activities are carried out both with the community and among Pokja members. The fifth stage is monitoring and evaluation. Monitoring and Evaluation is needed to see whether the process that has been implemented has been able to make the community critical in analyzing existing problems and to see whether the process that has been carried out is adequate or good or there are still many weaknesses. The results of this stage will be used as the basis for developing the next program.

\section{RESULTS AND DISCUSSION}

Several important results of learning with the participatory method (PRA) with the Sekaroh and Pemongkong communities are identified and discussed below: (1) increasingly demands for life, (2) conflict management natural resources, (3) unwise agricultural practices, (4) hereditary illegal grazing system, and (5) land ownership problems. While the results of the implementation of real learning with the community (action learning) in Sekaroh and Pemongkong for two years are: (1) the formation of a community linking "Penjuluk", (2) the formation of savings and loan groups, (3) the formation of activist cadres for forest management and critical land (4) increasing awareness of forest and critical land management, (5) increasing the ability of the Montong Bile community who are skilled at raising goats and (6) increasing the ability of the Erot community in srikaya gardening and mangroves planting.

\section{A. Several Community Problems}

\section{Community Life demands are getting heavier}

The fact shows that the changing policies that have been taking place so far have made people's lives more difficult. Farming carried out by the community before was able to meet the needs of the family; now it can no longer guarantee the fulfillment of these needs. This is closely related to the condition of the national economic crisis that occurred several times since mid-1997 and its effects are still being felt today. The difficulty of finding for alternative businesses outside the agricultural sector (that can be carried out by the existing community capabilities has prompted them to take shortcuts to do easy and fast-paying jobs, namely by cutting wood to get easy cash. To solve this problem is not easy. From the learning process with the Sekaroh and Pemongkong communities, it shows that there are still many alternative efforts in developing local resources that can be used to overcome poverty problems in this region. One of the efforts that can be done is to develop an integrated dryland farming system based on trees - food crops - grass and livestock. Results of field research on agroforestry initiated by the late TGH. Sibawai, documented by Suwardji et al. (2019), has proven that agroforestry development can improve land quality and at the same time improve community welfare. If this can be implemented, it is estimated that it can cut the cycle of poverty which is the main cause of forest and land destruction in this area. Other efforts to improve community welfare can be done through the management of the coastal and marine areas around Pemongkong and Sekaroh Villages. Community learning actions have also been carried out by the late TGH Sibawai have proven this through his teachings of the Eco Movement which has carried out rehabilitation of mangrove land in Pemongkong beach land for more than $6 \mathrm{Km}$ (Suwardji et al., 2019). Returning to the core issue that needs to be worked on seriously is how to commit to community empowerment at large. The Pemongkong community who used to be unable to get other income after farming, with the established mangroves (from the rehabilitation of coastal land with the community that was pioneered by TGH Sibawai) now after finishing working in their fields, can go to the mangrove forest and look for crabs. Within 2-3 hours alone, person can get 3-4 kg for IDR 50,000 per $\mathrm{kg}$. Increasing community income has been felt now and they are starting to realize the importance of maintaining and improving the quality of forests and degraded land.

\section{Natural Resource Management Conflict}

Natural resource management conflicts have existed for a long time. However, in the New Order era, these natural resource management conflicts did not arise because of the political structure that tended to be repressive. The changes in the political structure in the reform era and the implementation of regional autonomy today have led to openness in a wide variety of sectors, including information disclosure, so that conflicts over natural resource management are now popping up everywhere.

Changes in government policies in the era of regional autonomy and openness have had a broad impact on the wrong understanding of natural resource management. Forest management is not free from various disputes and to resolve it, it is necessary to involve all stakeholders and disputing parties. Forest and critical land management in the Sekaroh and Pemongkong areas is inseparable from various conflicts of interest. The conflict often happens between people who live in Sekaroh and Pemongkong and people who live outside Sekaroh and Pemongkong, between people with an interest in obtaining forest and land resources and people with an interest in obtaining business land, between cultivators and pastoralists and even other parties such as investors who want to invest in the region. They also carry out various businesses such as burning lime, coastal management and so on. One interesting example of the results of the joint study conducted by the Forest and Land Working Group with the community was that an agreement was obtained in three hamlets not to sell their land to outsiders if the land was not managed properly.

Studying together with communities around the forest in this area shows many conflicts in natural resource management, especially those related to forests and land. Among the triggers for this conflict are the existences of government policies that are less pro-community, but for logging activities by people from outside, illegal grazing, unclean governance, and so on. To overcome this problem, a strong facilitation is needed to be able to invite various disputing parties to sit together in designing common interests in the management of forest and land resources in this area. 
Only in this way can various conflicts of interest to be sought for solutions that can be agreed upon by the disputing parties.

\section{Unsustainable Agricultural Practices}

Without realizing it, the people living around the forest are still carrying out agricultural practices that actually damage the environment. The government has banned the practice of land burning at the start of the rainy season. However, the reality shows that people still practicing land burning before starting the planting season because they consider this method easy and cheap. In addition, pasture and shrub burning by pastoralists is still common, which often results in forest fires. If asked to the Sekaroh and Pemongkong people whom were wrong with unsustainable agricultural practices like this, it would be difficult to find answers.

Several agricultural and grazing practices in this area appear to be the main cause of frequent forest fires and the death of newly planted young plants. The various efforts that have been made have not been able to solve this problem. From two years of study with communities in the villages of Sekaroh and Pemongkong, there are indications that efforts to increase mutual awareness to pay attention to burning grass for plant preparation and burning grass in Imperata management are the most possible ways to reduce and avoid uncontrolled forest fires.

Raising awareness together to solve this problem, through strengthening the existing customary institutions in the community, is perhaps the most effective way to reduce the occurrence of forest fires. This has been proven by the people in Erot Hamlet and Montong Bile, Pemongkong Village who have implemented a collective customary agreement to minimize the occurrence of forest and land fires. However, to completely eliminate unwise agricultural practices as described above is very difficult to do, unless there are other alternatives that are easy and cheap and affordable to the community. Cost is still a major consideration in the development of agricultural practices carried out in Pemongkong and Sekaroh Villages.

\section{Hereditary Pastoral System}

The Sekaroh forest area holds a large potential source of animal feed. This has been proven by Suryanigsun and Suwardji (2009) in their research on the potential of wild plants in the Sekaroh area as animal feed. According to the narrative of the elderly in Sekaroh and Pemongkong villages, since hundreds of years ago this area was a pasture for cattle and buffalo grazing for people from Central Lombok (Pujut, Mujur ,ganti) and East Lombok (Rensing, Sakra, Keruak, Jerowaru) . During the rainy season when there is no place to graze their livestock in the places mentioned above (because they are planted with rice), livestock owners, through a skilled and professional herding system, herd their cattle to the Sekaroh Forest Area for months. Thousands to tens of thousands of livestock come to this area each year (Tejowulan et al, 2004). Even the herders have claimed their grazing area and have special places to prepare drinking water supplies for their livestock and temporary shelter for their shepherds when they are shepherding in Sekaroh and Pemongkong villages.

The problem that often arises in this pattern of illegal grazing is the journey to and from the Sekaroh area. On this trip, the animals often destroy the community's crops along the way. As a result, conflicts between herders and the community often occur because of the damage to crops caused by the grazing. From the results of studying with the community in Sekaroh and Pemongkong villages, it can be seen that by implementing a fine system through the traditional knowledge system developed by the community for livestock that damage their crops is quite effective in controlling crop damage caused by livestock grazing. However, in practice it is often difficult to determine the level of fines that are proportional to the level of damage to crops caused by uncontrolled grazing.

Apart from that, complex problems also arose when the government attempted to carry out reforestation and afforestation programs in forest areas and degraded land in the Sekaroh and Pemongkong areas. When the forests in this area were still in good condition, there were no significant problems in grazing practices. However, in the condition of the damaged forest as it is today, grazing is the main obstacle for the success of the reforestation. Pasture destroys the newly planted young plants and is an important cause of failure of reforestation and afforestation programs in the area. This problem becomes a complicated conflict and the right solution has not been found.

Based on the results of learning together with the community, it can be suggested that alternative solutions that might be done are to implement a rotating grazing zone by allocating a certain location as a controlled grazing area. In locations where planting and afforestation programs are carried out, grazing is not allowed at all. After the plant is large enough and it is believed that it will not be damaged by grazing, then it can be suggested to allow it to be used as a place for grazing again. This method does require substantial funds and human resources because it will involve the wider community in its implementation.

\section{Land Ownership Issues}

Land ownership status is a complex problem faced by the people of Sekaroh Village and Pemongkong. In general, the people in Sekaroh and Pemongkong Villages own quite large areas of land with an average ownership of more than two hectares per household. From existing land ownership, in general, the community is still unable to work on all the land they have due to limited manpower and funds. One of the important factors in managing the land they have is a weed problem which is quite heavy which is not easy to solve manually. This causes their limited ability to manage the land they own. Besides that, the production costs (farm labor wages, fertilizer price, and pesticides) are quite expensive while the prices of agricultural products produced are relatively cheap, causing farmers to be reluctant to exploit all their land to plant various types of crops.

In the Sekaroh and Pemongkong areas there are lands whose owners come from outside. Many of these lands are neglected and overgrown by thick enough shrubs, so that they 
are very potential as nesting sites for pig pests. To overcome the problem of pig pests, every dry season the community tries to reduce its population by carrying out mass pig hunting / mutual cooperation. To solve the problem of land ownership, the local government has also issued various regulations, however in practice some land owners who live outside Sekaroh and Pemongkong Villages still do not obey the rules set by the Village government. At this time the people of Sekaroh and Pemongkong villages have agreed to impose stricter customary regulations for outsiders from Sekaroh and Pemongkong villages who want to buy land in Sekaroh and Pemongkong. The land owner must really make use of it by following the awiq-awiq that the Pemongkong and Sekaroh villagers agree on.

\section{B. Experiences from Community Learning Action in Pemongkong and Sekaroh Villages}

\section{The Formation of The Community Linked People (Penjuluk)}

To make community empowerment efforts in the implementation of action learning in Pemongkong Village, it is understood by the community that a small group of connecting communities (Penjuluk) is needed who have good communication skills and commitment and strong awareness of the preservation of natural and environmental resources. In the initial period of activity implementation, with the facilitation of the Community Forest and Land Working Group, the community was able to determine the membership composition of the small community group. The result of further discussion decided that the group should be called the local language "Penjuluk". The Penjuluk was formed by the community in Erot Huts ( 7 people), Montong Bile ( 7 people) and Pemongkong (10 people). The penjuluk people during the action learning in Pemongkong Village are: (1) as a liaison between the Pokja and the whole community, (2) as a motivator, stimulator and dynamist for the entire community in managing forests and critical lands.

\section{The Formation of a Savings and Loan Group}

Savings and loan groups are formed by the community with the facilitation of a Pokja. The group's initial capital comes from the honorarium given during Pokja activities. The existence of this initial capital has succeeded in stimulating the community to save in a savings and loan group so that the group's capital has experienced a significant increase. The community's desire to promote savings and loans groups is because the community realizes the importance of the group's existence. When it comes to cheap rice / rice for the poor, the cash in the savings and loan group is very often used as capital to buy cheap rice. Then the group money is returned by the community within a long grace period. Apart from that, the group's savings and loans money is often used for the purchase of palawija seeds (beans) and tree crops.

\section{The Formation of Activist Cadres for Forest and Critical Land Management}

After the two year activities of the NTB Province Land and Forest Working Group ended, the Pokja continued its efforts to assist the community in managing forests and critical land in Pemongkong and Sekaroh Villages. To ensure the sustainability of the implementation of forest and critical land management in Pemongkong and Sekaroh Villages, the community, with the facilitation of the Pokja, forms a cadre. The membership of the cadres in each hut and the duties of the cadres are determined by the community. The tasks of each cadre formulated by the community are: (1) as a liaison between the Pokja and the community, (2) as a motivator for the wider community in managing forests and critical land in Sekaroh and Pemongkong, (3) coordinating the maintenance of goat livestock so as not to destroy the forest and its products part of it can be used to purchase plant seeds for greening the land in Pemongkong Village.

\section{Raising Awareness of Forest and Critical Land Management}

Observing the phenomenon of conflict over natural resources that continues to spread and various problems in the management of forests and critical lands that are increasingly complex, efforts to knit forests and restore critical land is not an easy task. Basically, efforts to raise awareness in proper environmental management are actions that can trigger the next concrete steps. This effort seems to need to be increased to build a strong foundation of togetherness to take other steps that need to be done.

The results of two years of learning with communities around the Sekaroh and Pemongkong forests were as follows. Efforts to raise awareness through meetings and field meetings show that planting awareness of environmental management early is very important and can raise awareness of the importance of good forest and critical land management. Learning while working to love trees by planting fruit and tree crops in the yard is a good first step to raise awareness of how important it is to plant trees in the fields and in the garden, maybe even awareness of maintaining state forests.

Self-interest initiates the awareness of planting trees in private yards and fields. But over time a collective awareness emerged of how to think about planting trees in state-owned forests. This awareness arises when the community understands the importance of forest functions, and starts restoring their own land which eventually continues with steps and efforts to restore state-owned land.

Increasing public collective awareness must of course be followed by an increase in the performance of government institutions and other related institutions. Various stories from the experiences of the Sekaroh and Pemongkong communities prove that the weak performance of government institutions has been an important factor in the failure of forest and critical land management programs in this region.

\section{The People of Montong Bile Are Skilled at Raising Goats}

Dusun Montong Bile Pemongkong Village is located about $1 \mathrm{~km}$ to the east of Pemongkong Hamlet. This hamlet has 36 families. The results of learning with the community have increased their awareness of the importance of planting trees and maintaining a clean environment. Their skills in raising 
goats should be used as basic capital in strengthening their institutions in various aspects of natural resource and environmental management. So that their increased ability to raise goats must be accompanied by their ability to keep the environment clean, including their ability to manage a clean goat pen.

Starting from the activities of raising goats and good farming activities, it seems that the people of Montong Bile can improve their institutions collectively. The existing biophysical conditions can support the development in this direction, especially the availability of adequate feed. The lessons learned so far have been able to increase their awareness of planting trees in their own yards. Some people even started buying tree seeds to plant in their own yards and in their fields. The combination of integrated goat and fruit tree farming, as well as food crop farming, seems to be able to make them more empowered and able to develop various institutional activities to manage forests and critical land in their regions.

The results of monitoring in the field show that during the two years of learning process, the awareness and pride of the people of Montong Bile Hamlet in planting trees and trying to care for and protect existing trees has increased rapidly. If this kind of awareness continues to be nurtured and their capacity building continues through various efforts, it is very possible that their involvement in forest and critical land management in their area will continue to increase as well.

\section{The Erot Community Who Are Skilled in Srikaya Gardening and Mangrove Planting}

Unlike the Montong Bile community, the Erot community which is located $1 \mathrm{~km}$ from Montong Bile has good skills in gardening and planting mangroves. Srikaya is a commodity that is very popular with the community. Some of the best conservation cadres are Erot residents and have become excellent conservation cadres for the NTB province. Some cadres have had good success in developing alley cropping for srikaya and tree crops such as mahogany and sengon.

However, because the results of the sengon which were previously promised to be sold at an attractive price (after the age of 5 - 7 years) could not be enjoyed, the community began to cut the sengon trees and replace them with other plants that had more economic value. In addition, the Erot community who were bombed by the religious leaders of TGH Sibawahi have been able to develop mangrove forests along the Erot coast for more than $6 \mathrm{~km}$, which are now very productive mangroves. The successes in improving the mangrove ecosystem that have been carried out over the years have yielded results.

Before the mangrove forest was successfully developed, the Erot community found it difficult to find crabs and various shellfish products. Currently, the location of the mangrove forest which has been successfully developed is a very busy place to find various marine products. The increase in income from catching crab, shellfish and other seafood in the afternoon by women generates high income for Erot residents. No less important is the fulfillment of animal protein from marine products which is expected to improve the quality of human resources for the people of Erot and its surroundings.

Even though some of the best conservation cadres are in this hamlet, the land conservation practices they have been working on in their fields and gardens have not been able to motivate most of Erot's residents to emulate them. From the results of the joint learning that was obtained with the community, it was found that their inability to follow in the footsteps of their conservational cadres was due to their economic powerlessness to do this. Guidance, mentoring, and stimulation given to them while studying together can increase their awareness and stimulate them to plant trees in their yards and fields.

Furthermore, increasing their awareness in the institution with the formation of joint savings and loans groups and various efforts to overcome their helplessness due to lack of capital, gradually began to be overcome. The stimulation of the provision of fruit and tree seedlings they want can develop awareness of the importance of managing their yards and fields. This stimulation has increased their extraordinary awareness of planting. Now, both as a group or individually, they are actively trying to procure seeds and plant both in their yards and fields.

\section{CONCLUSION}

Most of the forest and land conditions in the Province of West Nusa Tenggara (NTB) have been damaged and degraded quite badly. In Sekaroh Village and Pemongkong, East Lombok Regency, forest areas suffer the same fate: deforestation, land clearing, and use of forest land for agriculture have caused massive forest destruction.

Various efforts have been made to restore the function of forests with various biodiversity. The government through various related agencies has carried out various recovery programs, but they have not shown the expected results. Forest repair never came and critical land grew in number. It seems that the main obstacle in managing forest and critical land in Sekaroh and Pemongkong Villages lies in the socio-cultural problems of the community.

Sekaroh and Pemongkong villagers, who are migrants from various areas on Lombok Island and other areas, have pluralistic characteristics from both socio-economic and sociocultural backgrounds so that they have an impact on the diversity of views and behavior of the community in dealing with forests and critical land. In addition, the relatively low socio-economic conditions of the community have spurred the destruction of forests and critical lands.

The Forest and Land Working Group has tried to participate and struggle to overcome the problems of forest and critical land in Sekaroh and Pemongkong Villages by packaging a development paradigm that contains local potential both natural and human resources by emphasizing community learning (action learning) and community empowerment as development capital. The social capital paradigm that is built through real learning is social capital which is based on 
'togetherness', namely by trying to see the positive roles of social institutions to play.

\section{ACKNOWLEDGMENT}

We would like to thank Aus-AID for financial assistance to conduct this study and to the government of West Nusa Tenggara for its active roles and various supports during this two year field works. We would also like to thank Pemongkong and Sekaroh communities, leaders and cadres for all their time, effort and honest participation for the successful of this project.

\section{REFERENCES}

[1] Konsorsium Pengembangan Dataran Tinggi Nusa Tenggara. "Teknik Participatory", 2000.

[2] Anonymous. "Rapid Appraisal". Bahan Pelatihan Dasar Metode PRA", 2016.

[3] R. L. Oldeman, I. Las and Muladi. "The Climatic Map of Kalimantan, Maluku, Irian Jaya, and Bali West Nusatenggara and East Nusatenggara". Contrib. No.60. Centr. Res. Inst. Agric. Bogor Indonesia, 1980
[4] Suwardji, Sukartono, B.K. Kusumo, A. A. Bakti, P. Habibi, and M. Syaeful (2019), "Eco-Movement Berbasis Dakwah di Yayasan Darul Yatama Walmasakin Jerowaru Lombok Timur Melalui Media Teknologi dan Informatika", Seminar Nasional PEPADU, Hotel Grand Legi, 26 September 2019.

[5] Suwardji, Sukartono, B. H. Kusumo, A. A. Bakti, P. Habibi, "Kualitas Tanah Di Bawah Tegakan Agroforestri Tanaman Mahoni dan Sengon di Tanah Pasiran Lahan Sub Optimal Kering Pemongkong Lombok Timur Setelah 17 Tahun Penanaman", Seminar Nasional Saintek, Hotel Golden Palace, 3 Oktober 2019.

[6] Suryaningsun dan Suwardji, "Potensi Biomassa Tumbuhan Liar di Wilayah Sekaroh Lombok Timur Sebagai Sumber dan Penyedia Unsur Hara", Kongres Himpunan Ilmu Tanah Indonesia, UPN Yogyakarta, 19 November 2009.

[7] H. Tarningsih, E. Handayanto and Suwardji, "The Macroarthropod Diversities in Several Land System and Dryland Agroclimatic Zone in Lombok Island", Prosiding Nasional Seminar on Below Ground Biodiversity, Bandar Lampung, 29-30 Juni 2010 pp 72-89.

[8] R. S. Tejowulan, A. Cusson, and Suwardji, "Rehabilitasi Hutan dan Lahan Kritis: Belajar Dari Pengalaman Masyarakat", Aus-AID, $\begin{array}{lrrrr}\text { Denpasar } & \text { Bali } & 54 & \text { pages, } & 2004\end{array}$ 